\title{
HUBUNGAN KOLESTEROL NON-HDL TERHADAP FUNGSI KOGNITIF PADA PASIEN STROKE ISKEMIK DENGAN DEFISIT NEUROLOGIS RINGAN
}

\author{
A STUDY ON THE ASSOCIATION OF NON-HDL CHOLESTEROL AND \\ COGNITIVE FUNCTION IN MILD STROKE PATIENTS \\ Aylenia Lysandra, * Budi Riyanto Wreksoatmodjo, ** Josephine Retno Widayanti**
}

\section{ABSTRACT}

Introduction: Ischemic stroke patients have higher risk of cognitive decline. Severity of cognitive impairment depends on the severity of neurological deficit. The severity of cognitive impairment is also affected by abnormal non-HDL cholesterol level which includes atherogenic lipid that causes atherosclerosis.

Aim: Understanding the association of non-HDL cholesterol and cognitive function in mild stroke patients at Atma Jaya Hospital in 2014-2018.

Methods: A cross-sectional study by analyzing stroke registry patients (115 subjects). Data is analyzed by using Chi-square test and Fisher exact test.

Results: Total sample of this research is 115 respondents. Mean age was 58 11,286 years old and 30,4\% graduated from senior high school. 38,3\% have cognitive impairment measured by Mini Mental State Examination (MMSE), of which 79.5\% have abnormal non-HDL cholesterol. Meanwhile, 70,4\% have cognitive impairment measured by Montreal Cognitive Assessment Indonesian Version (MoCA-Ina), of which 76.5\% have abnormal non-HDL cholesterol. Cognitive function measured by MMSE and MoCA-Ina has no significant association with non-HDL cholesterol (respectively).

Discussion: This research contradicted the previous research. It is suspected that there is no direct relationship between non-HDL cholesterol and cognitive function. Besides, cholesterol acts as antioxidant, has a role in neurotransmission and has a protective effect.

Discussion: Cognitive function in patients with mild stroke, measured by MMSE and MoCA-Ina, is not associated with non-HDL Cholesterol.

Keywords: Cognitive function, ischemic stroke, mild stroke, non-HDL cholesterol

\section{ABSTRAK}

Pendahuluan: Pasien stroke iskemik memiliki risiko menderita gangguan kognitif. Derajat gangguan kognitif antara lain dipengaruhi tingkat defisit neurologis. Derajat gangguan kognitif juga dipengaruhi oleh kadar kolesterol non-high density lipoprotein (non-HDL) yang abnormal karena mengandung semua lipid aterogenik yang menyebabkan terjadinya aterosklerosis.

Tujuan: Mengetahui hubungan kadar kolesterol non-HDL terhadap gangguan kognitif pasien stroke iskemik terhadap defisit neurologis ringan di Rumah Sakit Atma Jaya pada tahun 2014-2018.

Metode: Penelitian potong lintang dengan menganalisis rekam medis pasien (115 subjek). Analisis data menggunakan uji Chi-square dan uji Fisher.

Hasil: Jumlah sampel pada penelitian ini adalah 115 orang. Rerata usia adalah $58 \pm 11,286$ tahun. Tingkat pendidikan dengan proporsi tertinggi adalah Sekolah Menengah Atas (SMA), yaitu 30,4\%. Berdasarkan Mini Mental State Examination (MMSE), 44 sampel (38,3\%) mempunyai gangguan kognitif, dan 79,5\% di antaranya memiliki kadar kolesterol non-HDL abnormal. Sementara itu, berdasarkan Montreal Cognitive Assessment Versi Indonesia (MoCA-Ina), 81 sampel (70,4\%) mempunyai gangguan kognitif, dan 76,5\% di antaranya memiliki kadar kolesterol non-HDL abnormal. Kolesterol nonHDL tidak berhubungan signifikan dengan fungsi kognitif yang diukur baik dengan MMSE maupun MoCA-Ina.

Diskusi: Penelitian ini bertentangan dengan penelitian sebelumnya. Hal ini disebabkan oleh tidak ada hubungan secara langsung antara kolesterol non-HDL dan fungsi kognitif. Selain itu, kolesterol berperan sebagai antioksidan yang membantu transmisi sinyal saraf dan bersifat neuroprotektor.

Kata kunci: Defisit neurologis ringan, fungsi kognitif, kolesterol non-HDL, stroke iskemik

*FKIK Universitas Katolik Indonesia Atma Jaya, Jakarta **Departemen Neurologi FKIK Universitas Katolik Indonesia Atma Jaya, Jakarta. Korespondensi: aylenial1@gmail.com.

\section{PENDAHULUAN}

Menurut Bank Dunia, sejak tahun 2010 hingga 2015, terjadi peningkatan angka kematian yang disebabkan oleh penyakit tidak menular di Indonesia dan penurunan angka kematian yang disebabkan oleh penyakit menular. ${ }^{1}$ Berdasarkan Global Burden 
of Disease, pada penyakit tidak menular, penyakit serebrovaskuler menempati urutan kedua penyebab kematian dan penyebab ketiga dalam penyebab utama kecacatan. ${ }^{2}$ Di Indonesia, menurut Riset Kesehatan Dasar (RISKESDAS) pada tahun 2013, prevalensi stroke berdasarkan diagnosis tenaga kesehatan sebesar 7 per 1000 penduduk dan yang terdiagnosis tenaga kesehatan maupun mempunyai gejala sebesar 12,1 per 1000 penduduk. ${ }^{3}$ Stroke mempunyai berbagai macam faktor risiko seperti usia, hipertensi, penyakit jantung, diabetes, herediter, kadar lemak dalam darah, merokok, obesitas, ras, kadar hematokrit, dan kontrasepsi oral, dan sebagainya. Stroke dapat menyebabkan gejala non-somatis seperti gangguan kognitif yang disebut sebagai vascular cognitive impairment dan hal ini mencakup spektrum vascular dementia dan mild cognitive impairment. Pasien stroke iskemik memiliki risiko yang lebih tinggi untuk menderita gangguan kognitif.

Gangguan vaskularisasi pada talamus dapat menyebabkan gangguan seperti gangguan fungsi sensorik, fungsi eksekutif, memori, bahasa, dan fungsi motorik. Semakin lama seseorang untuk dibawa ke rumah sakit maka proses infark akan terus berlangsung sehingga bagian otak yang rusak akan meluas meningkatkan tingkat keparahan stroke. Menurut P. Singh, dislipidemia memengaruhi kejadian gangguan kognitif vaskuler. ${ }^{4}$

Penelitian kohort di Perancis menemukan bahwa peningkatan kadar trigliserida berhubungan dengan besar volume white matter hyperintensity (WMH) dan lakunar pada MRI. Hal ini diduga karena trigliserida berhubungan dengan pemecahan sawah darah otak yang menyebabkan terbentuknya lakunar dan WMH. Selain itu kadar trigliserida diasosiasikan dengan marker inflamasi, dimana marker tersebut juga diasosiasikan dengan gambaran small vessel disease (SVD) pada MRI. Trigliserida juga mempengaruhi compliance arteri kecil yang mungkin menyebabkan hipoperfusi substansia alba. Menurut The Finnish Cardiovascular Risk Factors, Aging and Dementia (CAIDE), kadar total kolesterol pada usia midlife dapat memprediksi gangguan kognitif 21 tahun kemudian. Namun, penelitian kohort pada usia later-life menyatakan bahwa kadar kolesterol yang tinggi diasosiasikan dengan risiko yang lebih tinggi dan ada yang lebih rendah terhadap demensia vaskuler. ${ }^{5}$ Selain itu, penelitian Karossy dkk. menyatakan peningkatan kadar trigliserida dan LDL berhubungan dengan penurunan kemampuan memori. ${ }^{6}$

Menurut Yu An, kolesterol non-HDL memiliki hubungan positif dengan penurunan fungsi kognitif secara menyeluruh dan memiliki efek yang signifikan pada kadar $>5,2 \mathrm{mmol}$ dengan hazard ratio $1,54 .^{7}$ Selain itu, berdasarkan Journal of American Geriatric Society, ${ }^{8}$ orang dengan kadarnon-HDL $120 \mathrm{mg} / \mathrm{dL}$ atau $160 \mathrm{mg} / \mathrm{dL}$ memiliki risiko lebih tinggi untuk terjadi Alzheimer dementia. Penelitian yang dilakukan oleh $\mathrm{Da} \mathrm{Lu},{ }^{9}$ menyatakan bahwa peningkatan kadar serum non-HDL memengaruhi penurunan kognitif yang diperiksa dengan menggunakan Mini Mental State Examination (MMSE) dan Montreal Cognitive Assessment Versi Indonesia (MoCA-Ina). Hal ini dikarenakan kolesterol non-HDL meliputi kolesterolkolesterol aterogenik yang dapat memicu terjadinya pembentukan aterosklerosis. ${ }^{10}$

\section{TUJUAN}

Penelitian ini bertujuan untuk mengetahui hubungan kadar kolesterol non-HDL dengan gangguan kognitif pasien stroke iskemik dengan defisit neurologis ringan di Rumah Sakit Atma Jaya pada tahun 2014-2018.

\section{METODE}

Penelitian ini adalah penelitian analitik observasional yang dilaksanakan secara potong lintang. Sampel penelitian ini adalah pasien stroke iskemik dengan defisit neurologis ringan yang terdaftar di RS Atma Jaya pada tahun 2014-2018 yang memenuhi kriteria inklusi dan eksklusi.

Kriteria inklusi dalam penelitian ini adalah terdaftar dalam stroke registry RS Atma Jaya. Adapun kriteria eksklusi adalah pasien dengan kadar trigliserida $>500 \mathrm{mg} / \mathrm{dL}$ dan tidak memiliki data yang lengkap. Metode pengambilan sampel yang digunakan adalah sampel jenuh. Perkiraan besar sampel dengan rumus perhitungan besaran sampel deskriptif kategorik didapatkan sebanyak minimal 
97 orang. Persetujuan ethical clearance diperoleh dari komite etik penelitian pada manusia Fakultas Kedokteran dan Ilmu Kesehatan Universitas Katolik Atma Jaya melalui surat No:11/07/KEP-FKUAJ/2019 pada tanggal 1 Juli 2019.

Pada penelitian ini, variabel yang dianalisis adalah karakteristik pasien (usia, jenis kelamin, suku, dan tingkat pendidikan), kadar lipid (kolesterol total dan HDL), dan fungsi kognitif yang dinilai menggunakan MMSE dan MoCA-Ina. Diagnosis stroke iskemik berdasarkan gejala klinis dan gambaran CT scan kepala. Variabel bebas pada penelitian ini adalah kadar kolesterol Non-HDL sedangkan variabel tergantung dari penelitian ini adalah skor tes fungsi kognitif (MMSE \& MoCAIna). Kadar kolesterol non-HDL dikategorikan ke dalam dua kelompok, yaitu normal $(<130 \mathrm{mg} / \mathrm{dL})$ dan terganggu ( $\geq 130 \mathrm{mg} / \mathrm{dL}) .{ }^{11}$ Skor MMSE dimodifikasi menjadi bentuk dikotomi normal (24-30) dan terganggu (1-23). Selain itu, skor MMSE juga dibagi dalam tingkat pendidikan dimana ambang batas skor MMSE pada tingkat pendidikan tidak bersekolah adalah 12, ambang batas skor MMSE pada tingkat pendidikan tidak tamat SD adalah 18, ambang batas skor MMSE pada tingkat pendidikan SD adalah 22, ambang batas skor MMSE pada tingkat pendidikan SMP adalah 24, dan ambang batas skor MMSE pada tingkat pendidikan SMA dan seterusnya adalah 25. ${ }^{12-}$

${ }^{13}$ Skor MoCA-Ina disajikan dalam bentuk dikotomi normal (26-30) dan terganggu (1-25). ${ }^{14}$

Stroke iskemik dengan defisit neurologis ringan didefinisikan sebagai stroke iskemik dengan skor National Institute Health Stroke Scale (NIHSS) $\leq 5 .{ }^{15}$ Kadar kolesterol Non-HDL merupakan gabungan dari kolesterol aterogenik dan diukur dengan mengurangi kadar kolesterol HDL dari kadar total kolesterol. ${ }^{16}$

Analisis statistik menggunakan SPSS versi 25. Analisi univariat dilakukan untuk melihat karakteristik pada setiap variabel yang diteliti. Analisis bivariat dilakukan untuk mengetahui hubungan antara kolesterol non-HDL dengan skor MMSE dan MoCA-Ina. Hubungan dikatakan bermakna secara statistik jika nilai $\mathrm{p}<0,05$.

\section{HASIL}

Terdapat 124 sampel yang memenuhi kriteria inklusi, tetapi sebanyak 9 sampel dieksklusi karena tidak memiliki data yang lengkap. Proporsi jenis kelamin laki-laki $(50,4 \%)$ hampir sama dengan perempuan $(49,6 \%)$. Sebagian besar sampel berada di rentang usia 50-59 tahun (31,3\%), berasal dari suku jawa (53\%), dan memiliki tingkat pendidikan SMA (30,4\%) (Tabel 1).

Pada Tabel 2 dan Tabel 3, kadar kolesterol nonHDL tidak memiliki hubungan bermakna terhadap fungsi kognitif yang diukur dengan $\operatorname{MMSE}(p=0,793)$ dan MoCA-Ina $(p=0,491)$. Lebih jauh lagi, pada analisis subgroup berdasarkan tingkat pendidikan sampel, tidak terdapat hubungan bermakna antara kolesterol non-HDL dengan skor MMSE (Tabel 4).

\section{PEMBAHASAN}

Hasil penelitian menunjukkan bahwa jumlah pasien stroke iskemik pada laki-laki $(50,4 \%)$ tidak lebih banyak dibandingkan jumlah pasien stroke iskemik perempuan $(49,6 \%)$. Hal ini sesuai dengan penelitian World Journal of Clinical Cases dimana pria lebih banyak menderita stroke dibandingkan dengan wanita. ${ }^{17-18} \mathrm{Hal}$ ini diduga karena faktor gaya hidup seperti merokok dan konsumsi alkohol serta kondisi medis seperti hipertensi, obesitas, dan diabetes yang didapatkan lebih tinggi pada pria dibandingkan wanita. ${ }^{19}$ Selain itu, pasien stroke iskemik di dalam penelitian ini mempunyai rentang usia dari 34-86 tahun dimana jumlah pasien berusia $>45$ tahun lebih banyak dibandingkan dengan pasien stroke iskemik yang berusia $<45$ tahun. Hal ini sesuai dengan penelitian Ghanni dkk yang menyatakan bahwa sebagian besar kasus stroke terjadi pada pasien dengan usia lebih dari 45 tahun. Menurut American Heart Association (AHA), risiko seseorang untuk menderita penyakit stroke meningkat seiring dengan bertambahnya usia. ${ }^{18,20}$ Pada penelitian ini, sebagian besar responden berasal dari Suku Jawa. Hal ini sesuai dengan hasil Badan Pusat Statistik yang menyatakan bahwa Suku Jawa merupakan kelompok terbesar di Indonesia. ${ }^{21}$ Pada penelitian ini juga ditemukan lebih banyak pasien stroke iskemik mempunyai tingkat pendidikan SMA $(30,4 \%)$. Hal ini sejalan 
Tabel 1. Karakteristik Pasien $(n=115)$

\begin{tabular}{cc}
\hline Karakteristik & n (\%) \\
\hline
\end{tabular}

\section{Jenis Kelamin}

- Perempuan

- Laki-laki

$58(50,4)$

Usia (tahun)

- 30-39

- $40-49$

$24(20,9)$

- $50-59$

$36(31,3)$

- 60-69

$33(28,7)$

- 70-79

$13(11,3)$

- $80-89$

Usia (tahun), Rerata \pm SD

$58 \pm 11,286$

Suku

- Jawa

$61(53,0)$

- Sunda

$9(7,8)$

- Minang

$1(0,9)$

- Melayu

$1(0,9)$

- Cina

- Lainnya

$16(13,9)$

Tingkat Pendidikan

- Sarjana

- SMA

$35(30,4)$

- SMP

$19(16,5)$

- SD

$33(28,7)$

- Tidak tamat SD

- Tidak bersekolah

$15(13,0)$

$9(7,8)$

Kolesterol Non-HDI

- Normal

$20(21,7)$

- Terganggu

$95(78,3)$

Skor MMSE

- Normal

$71(61,7)$

- Terganggu

$44(38,3)$

Skor MoCA-Ina

- Normal

- Terganggu

$81(70,4)$

MMSE: Mini Mental State Examination; MoCA-Ina: Montreal Cognitive Assessment Versi Indonesia; Non-HDL: non-high density lipoprotein; SD: standar deviasi.

dengan penelitian Fakhruddin ${ }^{22}$ dan Festy $^{23}$ bahwa tingkat pendidikan pasien stroke terbanyak adalah SMA. Hal ini juga sesuai dengan penelitian yang dilakukan oleh Annisa ${ }^{24}$ yang menyatakan sebagian besar pasien stroke memiliki tingkat pendidikan rendah $(\leq \mathrm{SMA})$. Tingkat pendidikan diduga
Tabel 2. Hubungan Kolesterol Non-HDL dengan Skor MMSE $(\mathbf{n}=115)$

\begin{tabular}{|c|c|c|c|}
\hline \multirow{2}{*}{$\begin{array}{c}\text { Kadar Kolesterol } \\
\text { Non-HDL }\end{array}$} & \multicolumn{2}{|c|}{ MMSE } & \multirow[b]{2}{*}{$\mathbf{p}^{*}$} \\
\hline & $\begin{array}{c}\text { Normal } \\
\text { n }(\%)\end{array}$ & $\begin{array}{c}\text { Terganggu } \\
\text { n (\%) }\end{array}$ & \\
\hline Normal & $16(64,0)$ & $9(36,0)$ & \multirow{2}{*}{0,793} \\
\hline Terganggu & $55(61,1)$ & $35(38,9)$ & \\
\hline
\end{tabular}

Tabel 3. Hubungan Kolesterol Non-HDL dengan Skor MoCA-Ina $(n=115)$

\begin{tabular}{|c|c|c|c|}
\hline \multirow[b]{2}{*}{$\begin{array}{c}\text { Kadar Kolesterol } \\
\text { Non-HDL }\end{array}$} & \multicolumn{2}{|c|}{ MoCA-Ina } & \multirow[b]{2}{*}{$\mathbf{p}^{*}$} \\
\hline & $\begin{array}{c}\text { Normal } \\
\text { n }(\%)\end{array}$ & $\begin{array}{l}\text { Terganggu } \\
\text { n (\%) }\end{array}$ & \\
\hline Normal & $6(24,0)$ & $19(76,0)$ & \multirow{2}{*}{0,491} \\
\hline Terganggu & $28(31,1)$ & $62(68,9)$ & \\
\hline
\end{tabular}

*Uji Fisher; Non-HDL: non-high density lipoprotein; MoCAIna: Montreal Cognitive Assessment Versi Indonesia.

Tabel 4. Hubungan Kolesterol Non-HDL dengan Skor MMSE Berdasarkan Tingkat Pendidikan (n=115)

\begin{tabular}{ccc} 
Kolesterol Non- & \multicolumn{2}{c}{ MMSE } \\
\cline { 2 - 3 } HDL & $\begin{array}{c}\text { Normal } \\
\text { n (\%) }\end{array}$ & $\begin{array}{c}\text { Terganggu } \\
\text { n (\%) }\end{array}$ \\
\hline
\end{tabular}

Tidak Bersekolah

- Normal

$1(100)$

0

1,000

- Terganggu

$7(87,5)$

$1(12,5)$

Tidak Tamat SD

- Normal

1 (100)

0

1,000

- Terganggu

$11(78,6)$

$3(21,4)$

SD

- Normal

$5(50,0)$

$5(50,0)$

1,000

- Terganggu

$13(56,5)$

$10(43,5)$

SMP

- Normal

$4(80,0)$

$1(20,0)$

1,000

- Terganggu

$12(85,7) \quad 2(14,3)$

SMA dan Sarjana

- Normal

$$
6(75,0)
$$

$2(25,0)$

1,000

- Terganggu

$22(71,0)$

$9(29,0)$

*Uji Fisher; Non-HDL: non-highdensity lipoprotein; MMSE: Mini Mental State Examination.

berkaitan dengan kesadaran perilaku hidup sehat. Namun tingkat pendidikan pada negara berkembang dikaitkan dengan kemampuan konsumsi dan gaya hidup yang mengikuti hidup kebarat-baratan (western lifestyle) sehingga memengaruhi pola konsumsi yang cenderung pada makanan berisiko yang dapat 
berujung pada obesitas dan penyakit tidak menular lainnya. ${ }^{25}$

Pada penelitian ini, kolesterol non-HDL tidak memiliki hubungan yang signifikan dengan fungsi kognitif pada pasien stroke iskemik dengan tingkat defisit neurologis ringan. Teori saat ini menyatakan bahwa kolesterol non-HDL diduga menyebabkan gangguan kognitif karena terjadinya proses aterosklerosis yang mengakibatkan terjadinya penyempitan lumen pembuluh darah, sehingga terjadi penurunan alirah darah ke bagian otak tersebut dan menyebabkan hipoperfusi jaringan. ${ }^{26}$ Kondisi hipoperfusi ini menyebabkan hilangnya homeostasis ion sehingga terjadi influks ion natrium dan kalsium. Influks dari ion natrium menyebabkan terjadinya pembengkakan sel sehingga proses ini disebut cytotoxic edema. Influx dari ion kalsium menyebabkan produksi radikal bebas yang berlebihan yang akan merusak sel-sel neuron. ${ }^{27}$

Berdasarkan penelitian in vitro, ditemukan bahwa kolesterol dapat berperan sebagai antioksidan dengan cara memproduksi oxysterol yang lebih tidak toksik dibandingkan radikal bebas. ${ }^{28}$ Kolesterol yang tinggi diduga mempunyai efek protektif dengan meningkatkan enzim gamma-glutamyltransferase yang berperan dalam uptake asam amino dan transport sehingga mengurangi efek neurotoksik. ${ }^{29}$ Kolesterol juga berperan penting dalam sintesis, transport dan metabolisme hormon steroid dan vitamin larut lemak yang yang mempunyai dampak pada integritas sinaps dan neurotransmission..$^{30-32}$ Hal ini dapat terjadi karena selubung mielin yang kaya akan kolesterol mempunyai dampak meningkatkan transmisi sinyal saraf. ${ }^{33-34}$ Kolesterol yang terkandung dalam fosfolipid bilayer juga dapat membantu mencegah pembentukan radikal bebas. ${ }^{35}$ Selain itu, kolesterol juga berfungsi sebagai struktur lipid pada plasma membran, konsentrasi kolesterol yang rendah akan meningkatkan fluiditas dari membran plasma sehingga semakin rentan terhadap radikal bebas. ${ }^{36}$ Penelitian Yasuno dkk. menunjukkan tidak ada hubungan antara LDL, trigliserida, dan total kolesterol dengan fungsi kognitif. ${ }^{6}$

Faktor lain yang dapat memengaruhi hasil penelitian adalah pernikahan. ${ }^{37}$ Menurut Krister
Håkansson, ${ }^{38}$ terdapat hubungan antara status pernikahan dengan fungsi kognitif pada usia lanjut dimana pada orang yang tidak mempunyai pasangan hidup memiliki risiko dua kali lebih tinggi untuk terjadi gangguan kognitif dan demensia Alzehimer dibandingkan dengan orang yang mempunyai pasangan hidup. ${ }^{39}$ Menikah mempunyai beberapa keuntungan yang dapat memengaruhi kesehatan kognitif seperti akses sumber ekonomi, status nutrisi yang lebih baik, dan perawatan selama sakit. Selain itu, dengan adanya pasangan hidup, maka mendapatkan dukungan sosial seperti kasih sayang, saran, dan perawatan, serta memperluas komunikasi dengan berhubungan melalui keluarga dan teman dari pasangan hidup tersebut. ${ }^{40}$

Duering dkk menyatakan bahwa infark lakunar di bagian talamus dan ganglia basal menyebabkan penurunan fungsi kognitif yang lebih besar dibandingkan dengan infark di area substansia alba. Hal ini menunjukkan bahwa bukan luas lesi yang menyebabkan terjadinya gangguan kognitif. ${ }^{41-42}$

Pada Tabel 4 menunjukkan bahwa tidak ada hubungan yang bermakna antara kolesterol nonHDL terhadap fungsi kognitif yang diklasifikasikan berdasarkan tingkat pendidikan. Hal ini diduga karena jumlah responden pada tiap tingkat pendidikan sedikit. Selain itu, fungsi kognitif juga dipengaruhi oleh berbagai macam faktor yang tidak dapat dieksklusikan pada penelitian ini.

Keterbatasan penelitian ini adalah peneliti tidak mendapatkan data penyakit terdahulu secara detail dan juga tidak dapat mengeksklusikan faktor perancu seperti pernikahan yang dapat memengaruhi hasil penelitian.

\section{KESIMPULAN}

Pada pasien stroke iskemik dengan defisit neurologis ringan, kadar kolesterol non-HDL tidak memiliki hubungan yang signifikan dengan fungsi kognitif.

\section{DAFTAR PUSTAKA}

1. State and Outlook 2015. Changing disease burdens and risks of pandemics (GMT 3). European Environment Agency [serial online]. 2015 [diunduh 5 Mei 2020]. Tersedia dari: European Environment Agency. 
2. World Bank. Cause of death, by non-communicable diseases (\% of total). World Bank [serial online]. 2019 [diunduh 5 Mei 2020]. Tersedia dari: World Bank.

3. Kementerian Kesehatan RI. RISKESDAS 2013. 2013.

4. Singh P, Dhiran A, Dangi V. Clinical risk factors associated with post stroke vascular cognitive impairment. GJRA. 2018;16:7(4):165-8.

5. Appleton J, Scutt P, Sprigg N, Bath P. Hypercholesterolaemia and vascular dementia. Clin Sci. 2017;131(14):1561-78.

6. Yuda Turana. Stop pikun di usia muda. Edisi Revisi. Jakarta: Gramedia Pustaka Utama; 2020. h.28

7. An Y, Zhang X, Wang Y, Wang Y, Liu W, Wang T, dkk. Longitudinal and nonlinear relations of dietary and serum cholesterol in midlife with cognitive decline: results from EMCOA study. Mol Neurodegener. 2019;14(1):1-9.

8. Marcum ZA, Walker R, Bobb JF, Sin MK, Gray SL, Bowen JD, dkk. Serum cholesterol and incident Alzheimer's disease: findings from the adult changes in Thought study. J Am Geriatr Soc. 2018;66(12):2344-52.

9. Lu D, Li P, Zhou Y, Xu X, Zhang H, Liu L, T ian Z. Association between serum non-high-density lipoprotein cholesterol and cognitive impairment in patients with acute ischemic stroke. BMC Neurol. 2016;16(1):154.

10. Ma C, Yin Z, Zhu P, Luo J, Shi X, Gao X. Blood cholesterol in late-life and cognitive decline: a longitudinal study of the Chinese elderly. Mol Neurodegener. 2017;12(1):24.

11. Jacobson T, Ito M, Maki K, Orringer C, Bays H, Jones $\mathrm{P}$, dkk. National lipid association recommendations for patient-centered manag ement of dyslipidemia: part 1-full report. J Clin Lipido;. 2015;9(2):129-69.

12. Indonesia PD. Panduan praktik klinis neurologi. Jakarta: Perhimpunan Dokter Spesialis Saraf Indonesia; 2016.

13. Wreksoatmodjo BR. Pengaruh aktivitas fisik terhadap fungsi kognitif lanjut usia di Jakarta Barat. Cermin Dunia Kedokteran. 2016;43(1):07-12.

14. Suda S, Muraga K, Ishiwata A, Nishimura T, Aoki J, Kanamaru T dkk. Early cognitive assessment following acute stroke: feasibility and comparison between mini-mental state examination and montreal cognitive assessment. J Stroke Cerebrovasc Dis. In press 2020.

15. Spokoyny I, Raman R, Ernstrom K, Khatri P, Meyer DM, Hemmen TM, dkk. Defining mild stroke: outcomes analysis of treated and untreated mild stroke patients. J Stroke Cerebrovasc Dis. 2015;24(6):1276-81.

16. Puri R, Nissen SE, Shao M, Elshazly MB, Kataoka Y, Kapadia SR, dkk. Non-HDL cholesterol and triglycerides: implications for coronary atheroma progression and clinical events. Arterioscler Thromb Vasc Biol. 2016;36(11):2220-8.

17. Barker-Collo S, Bennett DA, Krishnamurthi R V, Parmar P, Feigin VL, Naghavi M, dkk. Sex differences in stroke incidence, prevalence, mortality and disability-adjusted life years: results from the Global Burden of Dis ease Study 2013. Neuroepidemiol. 2015;45(3):203-14.

18. Arboix A. Cardiovascular risk factors for acute stroke: risk profiles in the different subtypes of ischemic stroke. WJCC. 2015;16;3(5):418.

19. Centers for Disease Control and Prevention. Men and stroke. Centers for Disease Control and Prevention [serial online]. 2019. Tersedia dari: Centers for Disease Control and Prevention.

20. Roy-O'Reilly M, McCullough LD. Age and sex are critical factors in ischemic stroke pathology. Endocrinology. 2018;159(8):3120-31.

21. Badan Pusat Statistik. Jawa mendominasi 40 persen suku bangsa di Indonesia. Databoks [serial online]. 2019 [diunduh 5 December 2019]. Tersedia dari: Databoks: Pusat Data Ekonomi dan Bisnis Indonesia.

22. Fakhruddin H, Nurmalia L. Perbandingan uji diagnostik siriraj stroke score dan algoritma stroke Gadjah Mada sebagai prediktor jenis stroke di RS Sentra Medika Bekasi. Jurnal Kedokteran Universitas Lampung. 2019;3(2):251-8.

23. Virgonita KA. Hubungan clinical pathway stroke iskemik terhadap average length of stay di RS PKU Muhammadiyah Yogyakarta [disertasi]. Yogyakarta: Universitas Gadjah Mada; 2018.

24. Putri AI, Kodim N. Frekuensi dan determinan kejadian stroke pada penderita hipertensi dewasa di wilayah pedesaan Indonesia tahun 2013. Depok: Universitas Indonesia; 2015.

25. Monteiro CA, Moura EC, Conde WL, Popkin BM. Socioeconomic status and obesity in adult populations of developing countries: a review. Bulletin of the World Health Organization. 2004;82:940-6.

26. Banerjee C, Chimowitz MI. Stroke caused by atherosclerosis of the major intracranial arteries. Circ Res. 2017;120(3):502-13.

27. Sarkar S, Chakraborty D, Bhowmik A, Ghosh MK. Cerebral ischemic stroke: cellular fate and therapeutic opportunities. Front Biosci. 2019;24:435-50.

28. Mielke MM, Zandi PP, Sjögren M, Gustafson D, Ostling S, Steen B, dkk. High total cholesterol levels in late life associated with a reduced risk of dementia. Neurology. 2005;64:1689-95.

29. Dziedzic T, Slowik A, Gryz EA, Szczudlik A. Lower serum triglyceride level is associated with increased stroke severity. Stroke. 2004;35:e151-2. 
30. Koudinov AR, Koudinova NV. Essential role for cholesterol in synaptic plasticity and neuronal degeneration. FASEB J. 2001;15:1858-60.

31. Oliver MF. Serum cholesterol-the knave of hearts and the joker. Lancet . 1981;2:1090-5.

32. Traber MG, Kayden HJ. Vitamin E is delivered to cells via the high affinity receptor for low-density lipoprotein. Am J Clin Nutr.1984;40:747-51.

33. Vance JE. Dysregulation of cholesterol balance in the brain: Contribution to neurodegenerative diseases. Dis Model Mech. 2012;5:746-55.

34. Petrov AM, Zefirov AL. Cholesterol and lipid rafts in the biological membranes. Role in the release, reception and ion channel functions. Uspekhi fiziologicheskikh nauk. 2013;44(1):17-38.

35. Parasassi T, Giusti AM, Raimondi M, Ravagnan G, Sapora O, Gratton E. Cholesterol protects the phospholipid bilayer from oxidative damage. Free Radic Biol Med. 1995;19(4):511-6.

36. Van der Paal J, Neyts EC, Verlackt CC, Bogaerts A. Effect of lipid peroxidation on membrane permeability of cancer and normal cells subjected to oxidative stress. Chem Sci. 2016;7(1):489-98.

37. Håkansson K, Rovio S, Helkala EL, Vilska AR, Winblad B, Soininen H, dkk. Association between mid-life marital status and cognitive function in later life: population based cohort study. BMJ. 2009;339:b2462.

38. Liu H, Zhang Y, Burgard SA, Needham BL. Marital status and cognitive impairment in the United States: evidence from the national health and aging trends study. Ann Epidemiol. 2019;38:28-34

39. Waite LJ, Gallagher M. The case for marriage: why married people are happier, healthier, and better off financially. New York, NY: Broadway Books; 2000. h.60.

40. Ross CE, Mirowsky J, Goldsteen K. The impact of family on health: the decade in review. J Marriage Fam. 1990;52:1059-78.

41. Zulkifly MF, Ghazali SE, Din NC, Singh DK, Subramaniam P. A Review of risk factors for cognitive impairment in stroke survivors. The Scientific World Journal. 2016;2016:3456943.

42. Putri MN, Mutiawati E, Mahdani W. Hubungan derajat stroke terhadap status kognitif pada pasien stroke iskemik di poliklinik saraf rumah sakit umum daerah dr. Zainoel Abidin Banda Aceh. Jurnal Ilmiah Mahasiswa Kedokteran Medisia. 2017;2(1):61-7. 